\title{
Purification and properties of $3^{\prime}$-nucleotidase of Leishmania donovani
}

\author{
George O. GBENLE* $\ddagger$ and Dennis M. DWYER $\dagger$ \\ * Department of Biochemistry, College of Medicine of the University of Lagos, P.M.B. 12003, Lagos, Nigeria, \\ and † Cell Biology and Immunology Section, Laboratory of Parasitic Diseases, National Institutes of Health, \\ Bethesda, MD 20892, U.S.A.
}

\begin{abstract}
A surface membrane 3'-nucleotidase from Leishmania donovani promastigotes has been purified to SDS/PAGE homogeneity. The enzyme has apparent subunit molecular mass of $38 \mathrm{kDa}, \mathrm{pI} 5.8$ and a broad $\mathrm{pH}$ optimum, 5.5-7.5. EDTA partially inhibited the enzyme activity, which was fully restored by $\mathrm{Co}^{2+} ; \mathrm{Mg}^{2+}, \mathrm{Ca}^{2+}$ or $\mathrm{Mn}^{2+}$ had no effect on the activity. $\mathrm{ZnCl}_{2}$ or dithiothreitol at $1 \mathrm{mM}$ was inhibitory at $\mathrm{pH} 7.5$, but was without effect at $\mathrm{pH} 5.5$, whereas at both $\mathrm{pH}$ values $5 \mathrm{~mm}$ of either compound inhibited the enzyme. The substrate-specificity of the purified enzyme is restricted to ribonucleoside 3'-phosphates. 3'-AMP and 3'-IMP are the best substrates, whereas ADP, ATP, 2'-deoxyadenosine 3'phosphate and 5'-AMP are competitive inhibitors of the enzyme. The enzyme showed low latency in intact-cell preparations. The kinetic properties and the surface membrane localization of the enzyme suggest its implication in the formation of nucleosides from 3'-nucleotides of the parasite's host.
\end{abstract}

\section{INTRODUCTION}

Several species of the protozoan family Trypanosomatidae have surface-membrane-bound 3'-nucleotidase (EC 3.1.3.6). These trypanosomatids include Leishmania [1,2] and African trypanosomes $[3,4]$, which are pathogenic parasites of man, as well as Crithidia luciliae [5], a non-pathogenic parasite of insects. 5 -Nucleotidase (EC 3.1.3.5) activity has also been detected in Leishmania species [6,7], but is apparently absent from Trypanosoma brucei [2] and T. rhodesiense [8]. 5'-Nucleotidases are widespread in mammalian cells, where they occur as plasmamembrane-bound enzymes [9] responsible for producing adenosine extracellularly [10], and as cytosolic enzymes implicated in the intracellular formation of adenosine from AMP [11,12] or of inosine from IMP [13]. 3'-Nucleotidase is generally not associated with mammalian cells [14], even though 3'-nucleotides are available through nucleic acid hydrolysis in several mammalian tissues, especially the spleen [15], where leishmanial parasites could reside in susceptible mammals. Therefore, since the plasma membrane is permeable to nucleosides rather than nucleotides, it seems likely that the physiological role for the leishmanial enzyme is the processing of exogenously available $3^{\prime}$-nucleotides into a form suitable for transport across the surface membrane of the parasite, which is incapable of purine synthesis de novo [16].

It is necessary to purify an enzyme to homogeneity in order to study its regulation and, in this case, its role in the host-parasite relationship at the molecular level. The purification of $3^{\prime}$ nucleotidase with an associated nuclease activity from the nonpathogenic insect parasite $C$. luciliae [5] was recently reported. However, despite the high activity of $3^{\prime}$-nucleotidase in homogenate and membrane extracts of leishmanias and the potential interest in its exploitation for therapy of the diseases they cause, there has been no report of the purification of the enzyme from Leishmania. In the present paper, we report the purification of $L$. donovani 3'-nucleotidase and also describe some of its properties. The substrate specificity, enzyme reaction and inhibition kinetics as well as the surface-membrane localization of this leishmanial enzyme suggest its implication in the formation of nucleosides from 3 -ribonucleosides in mammalian host.

\section{MATERIALS AND METHODS}

\section{Chemicals}

All the nucleotides used were obtained from Sigma. Concanavalin A (Con A)-Sepharose and DEAE-Sephacel were purchased from Pharmacia. Octyl $\beta$-D-glucopyranoside (octyl glucoside) and CHAPS were obtained from Calbiochem, and Triton X-100 (specially purified) was from Pierce. All other reagents used were of the highest purity commercially obtainable.

\section{Parasites}

A cloned line of $L$. donovani (strain 15) was maintained by continuous passage in tissue-culture medium 199 (M 199) supplemented with $10 \%(\mathrm{v} / \mathrm{v})$ fetal-calf serum. For large-scale cultivation, the parasites were grown in $200 \mathrm{ml}$ of medium in $500 \mathrm{~cm}^{2}$ tissue-culture flasks. The cells were harvested at $4{ }^{\circ} \mathrm{C}$ by centrifugation and washed twice in $10 \mathrm{~mm}-\mathrm{Tris} / \mathrm{HCl}$ (pH 7.5)/145 mM-NaCl.

\section{Enzyme assays}

Standard reaction mixtures $(100 \mu \mathrm{l})$ for $3^{\prime}$-nucleotidase assays contained 80 mM-Hepes (pH 7.5)/0.1\% CHAPS, 2.5 mM-3'AMP and a portion of enzyme. The 5 -nucleotidase reaction mixture (100 $\mu \mathrm{l}$ ) contained $80 \mathrm{~mm}-\mathrm{Mes}(\mathrm{pH} 6.5) / 0.1 \%$ CHAPS, $2.5 \mathrm{mM}-5^{\prime}$-AMP and enzyme. The reaction mixtures were incubated at $37^{\circ} \mathrm{C}$ for $30 \mathrm{~min}$, stopped by chilling in an ice-bath, and the amount of $P_{1}$ released was estimated as described by Lanzetta et al. [17]. Units of enzyme activity are expressed as $\mu \mathrm{mol}$ of $P_{1}$ released $/ \mathrm{min}$. The assays were performed at protein concentrations and over periods for which the reaction was linear. Nuclease activity was determined by measuring the $A_{260}$ of acid/ethanol-soluble product released from poly(A) by the enzyme as described previously [18]. Acid phosphatase was assayed by measuring the $A_{410}$ of $p$-nitrophenol released from $p$ nitrophenyl phosphate at $\mathrm{pH}$. Alanine aminotransferase was measured essentially as described in [19]. For all enzyme assays, separate controls which lacked enzyme but contained the substrate and other materials as in the test reaction mixture were used. Furthermore, for some enzyme fraction assays, the control 
Table 1. Purification of 3'-nucleotidase from Leishmania donovani

3'-Nucleotidase standard assay and protein determination were as described in the Materials and methods section.

\begin{tabular}{lccccc}
\hline & $\begin{array}{c}\text { Total } \\
\text { activity } \\
\text { (units) }\end{array}$ & $\begin{array}{c}\text { Total } \\
\text { protein } \\
\text { (mg) }\end{array}$ & $\begin{array}{c}\text { Specific } \\
\text { activity } \\
\text { (units/mg) }\end{array}$ & $\begin{array}{c}\text { Purification } \\
\text { (fold) }\end{array}$ & $\begin{array}{c}\text { Recovery } \\
(\%)\end{array}$ \\
\hline Homogenate & 3101 & 585 & 5.3 & 1.0 & 100 \\
8000 g pellet & 2760 & 223 & 12.4 & 2.3 & 8.5 \\
Detergent extract & 1895 & 79.6 & 23.8 & 9.3 & 89 \\
Con A-Sepharose & 1276 & 25.9 & 473 & 3.1 & 29.7 \\
DEAE-Sephacel & 922 & 1.8 & 2345 & 349 & 16.6
\end{tabular}

reaction mixture contained enzyme added after termination of the reaction. The values obtained from such controls were subtracted as background from experimental determinations.

Protein concentrations were estimated by measuring the $A_{280}$ of chromatographic column eluates, or colorimetrically for enzyme fractions by using bicinchoninic acid [20].

\section{Purification of $3^{\prime}$-nucleotidase}

Unless otherwise stated, all steps were performed at $0.4^{\circ} \mathrm{C}$.

Detergent extraction. The washed cells (total of $1.2 \times 10^{11}$ organisms) were lysed by resuspending the cell pellets in a solution containing $5 \times 10^{8}$ cells $/ \mathrm{ml}$ of hypo-osmotic buffer [10 mM-Tris/HCl (pH 7.2)/1 mM-EDTA/25 $\mu \mathrm{g}$ of leupeptin $/ \mathrm{ml}]$ and homogenized manually in a Dounce homogenizer. Over $90 \%$ of the cells were disrupted, as determined by phase-contrast microscopy. The homogenate was centrifuged at $8000 \mathrm{~g}$ for $30 \mathrm{~min}$. The pellet was extracted with $60 \mathrm{ml}$ of $0.5 \%$ Triton X100 in $20 \mathrm{~mm}$-Tris/ $\mathrm{HCl}, \mathrm{pH} 7.2$, for $4 \mathrm{~h}$ with rocking, centrifuged at $8000 \mathrm{~g}$ for $30 \mathrm{~min}$, and the supernatant (Triton X-100 extract) was kept. The resulting pellet was re-extracted with $45 \mathrm{ml}$ of $1 \%$ octyl glucoside in $20 \mathrm{mM}$-Tris/ $\mathrm{HCl}, \mathrm{pH} \mathrm{7.2,} \mathrm{for} 4 \mathrm{~h}$ with rocking, and centrifuged at $8000 \mathrm{~g}$ for $30 \mathrm{~min}$. The supernatant was pooled with the Triton X-100 extract.

Con A-Sepharose chromatography. The pooled detergent extract $(102 \mathrm{ml})$ was applied to a $1.2 \mathrm{~cm} \times 25 \mathrm{~cm}$ column of Con ASepharose equilibrated in buffer A [20 mM-Tris/ $\mathrm{HCl}$ (pH 7.2)/ $0.2 \%$ Triton $\mathrm{X}-100 / 1 \mathrm{mM}^{-\mathrm{NaN}_{3}}$ ]. The column was washed with $120 \mathrm{ml}$ of buffer $\mathrm{A}$ before elution with buffer A containing 50 mM-methyl $\alpha$-D-mannopyranoside and $1 \%$ octyl glucoside. Fractions $(7.5 \mathrm{ml})$ at a flow rate of $0.5 \mathrm{ml} / \mathrm{min}$ were collected and assayed for 3'-nucleotidase activity and protein.

DEAE-Sephacel chromatography. Enzyme fractions from Con A-Sepharose were pooled and applied to a $1.2 \mathrm{~cm} \times 10 \mathrm{~cm}$ column of DEAE-Sephacel equilibrated in buffer B [ $20 \mathrm{~mm}-\mathrm{Tris} / \mathrm{HCl}$ (pH 7.2)/0.2\% Triton X-100/1\% octyl glucoside $/ 5 \%$ glycerol/ $1 \mathrm{mM}-\mathrm{NaN}_{3}$ ]. The column was washed with $50 \mathrm{ml}$ of buffer $\mathrm{B}$ containing $25 \mathrm{~mm}-\mathrm{NaCl}$ before elution with a $150 \mathrm{ml}$ linear gradient of $25-250 \mathrm{~mm}-\mathrm{NaCl}$ in buffer B. Fractions $(5 \mathrm{ml})$ were collected at a flow rate of $0.4 \mathrm{ml} / \mathrm{min}$, and those with $3^{\prime}$ nucleotidase activity were pooled.

Isoelectric focusing (IEF). The DEAE-Sephacel pooled fraction $(60 \mathrm{ml})$ was concentrated 24-fold in a Centriprep 10 microconcentrator (Amicon), diluted 32-fold with buffer C [10 mMHepes ( $\mathrm{pH} 7.0) / 0.01 \%$ CHAPS] and finally concentrated to $0.5 \mathrm{ml}$ in the micro-concentrator. To this concentrate was added $1 \mathrm{ml}$ of $40 \% \mathrm{pH} \mathrm{3-10} \mathrm{carrier} \mathrm{ampholytes,} \mathrm{and} \mathrm{the} \mathrm{mixture} \mathrm{was}$ made up to $40 \mathrm{ml}$ with $0.1 \%$ CHAPS in deionized water. This mixture was electrofocused in Rotofor preparative IEF cell (BioRad) with $0.1 \mathrm{M}$-acetic acid and $0.1 \mathrm{M}-\mathrm{NaOH}$ as anodic and cathodic electrolyte respectively. Fractions collected after the electrofocusing run were assayed for 3 '-nucleotidase activity, and
pH values were determined. Fractions containing enzyme activity were pooled, diluted 4-fold in buffer $\mathrm{C}$ and then concentrated to $2.5 \mathrm{ml}$ in a Centriprep 10 micro-concentrator.

Gel electrophoresis and staining. SDS/PAGE on slab gel was performed by the method of Laemmli [21], with $4 \%$ acrylamide in the stacking gel and $10 \%$ acrylamide for the separating gel. One half of the electrophoresed slab gel was stained for protein with the Rapid-Ag staining kit (ICN), according to the manufacturers' instructions. The other half of the gel, containing sample lanes identical with those in the first half, was stained for $3^{\prime}$-nucleotidase essentially as described in [22].

\section{Latency}

For latency experiments, the 3 '-nucleotidase and alanine aminotransferase assay mixtures were supplemented with $0.25 \mathrm{M}$ sucrose and $5 \mathrm{~mm}$-glucose, and the reaction started by addition of intact cells (in the presence and absence of $0.1 \%$ Triton $\mathrm{X}$ 100). The reaction was stopped after $10 \mathrm{~min}$ at $37^{\circ} \mathrm{C}$.

\section{RESULTS}

\section{Purification of $L$. donovani 3 '-nucleotidase}

The purification results are summarized in Table 1 . The membrane fraction ( $8000 \mathrm{~g}$ or ' $8 \mathrm{~K}$ ' pellet) contained $90 \%$ of the total 3 '-nucleotidase activity in the cell homogenate. This result, together with the requirement for both detergents, Triton X-100 and octyl glucoside, for solubilization of the enzyme from the membrane pellet, indicated that $3^{\prime}$-nucleotidase is an integral membrane protein. Some $40 \%$ of the enzyme activity in the membrane pellet was recovered by Triton X-100, and a further $30 \%$ was recovered by re-extraction with octyl glucoside. 5'Nucleotidase activity was about 7 -fold less than the 3 '-nucleotidase activity in the homogenate and about 20 -fold less in the membrane fraction, but was not detected in further purification steps. All the 3'-nucleotidase activity applied to the Con ASepharose was bound to the lectin affinity gel, from which about $70 \%$ of the activity was eluted by $50 \mathrm{mM}$-methyl $\alpha$-D-manopyranoside (Fig. 1). This indicates that the enzyme is a mannosecontaining glycoprotein. The highest increase in specific activity of 3 -nucleotidase between purification steps occurred when the Con A-Sepharose pooled fractions were further fractionated on a DEAE-Sephacel column (Fig. 2). The specific activity was increased 10 -fold by this step, and $68 \%$ of the applied enzyme activity was recovered (Table 1).

Enzyme from each purification step was also analysed on SDS/PAGE, followed by silver-staining and staining for 3'nucleotidase activity (Fig. 3). The enzyme from the DEAESephacel step showed the presence of two prominent silverstained bands at about $43 \mathrm{kDa}$ and $38 \mathrm{kDa}$; a few minor protein bands were also observed. The IEF fraction revealed a 


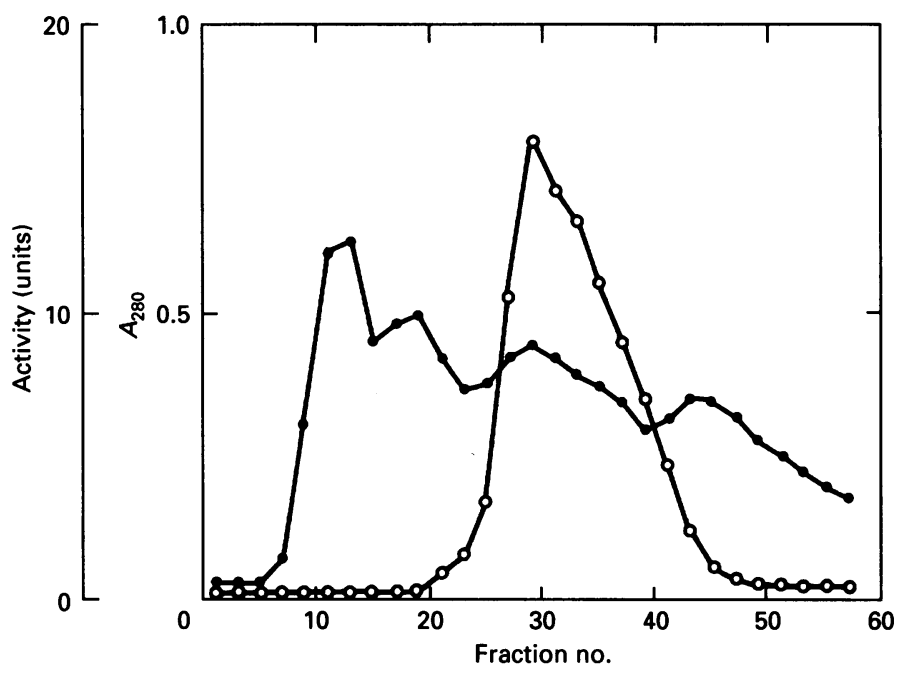

Fig. 1. Chromatographic purification on Con A-Sepharose

The sample-loaded column was washed with column equilibration buffer before elution with buffer containing $50 \mathrm{~mm}$-methyl $\alpha$-Dmannopyranoside and $1 \%$ octyl glucoside, starting from column fraction 15. For details, see the Materials and methods section. $\bigcirc$, 3 '-Nucleotidase activity; $\bigcirc, A_{280}$.

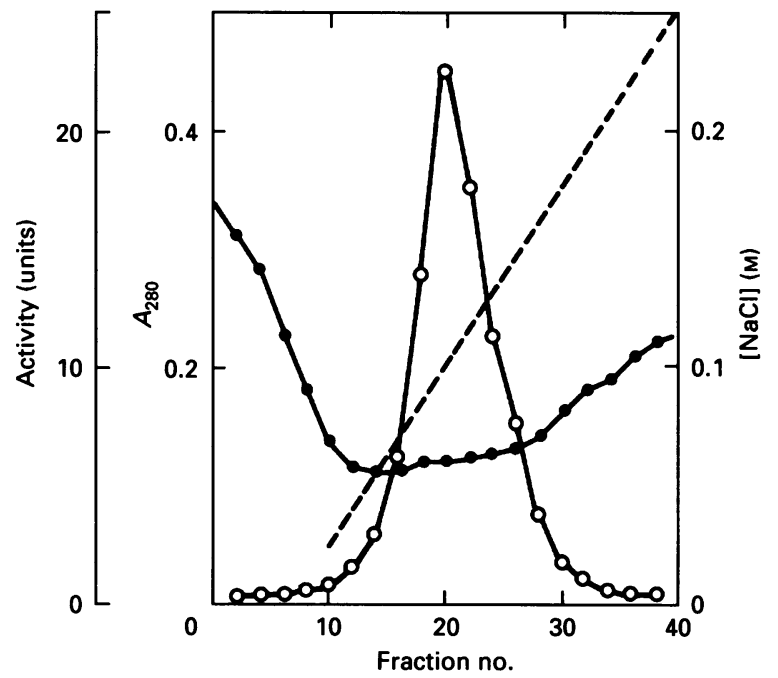

Fig. 2. Chromatographic purification on DEAE-Sephacel

See the Materials and methods section for details. $O, 3^{\prime}$-Nucleotidase activity;,$A_{\mathbf{2 8 0}} ;----,[\mathrm{NaCl}]$.

single prominent silver-stained band at approx. $38 \mathrm{kDa}$ which co-migrated with the enzyme-activity band (Fig. 3). The two minor silver-stained bands of slower mobility also observed were artifacts, since gel lanes containing sample buffer only revealed the same bands (results not shown). Each of the crude (or partially purified) extracts and the purified fraction exhibited a single 3 '-nucleotidase activity band which co-migrated with a silver-stained band at $38 \mathrm{kDa}$ (results partly shown in Fig. 3). This result indicates that $L$. donovani has only one 3 '-nucleotidase type, with subunit molecular mass of $38 \mathrm{kDa}$.

The purified 3 -nucleotidase was free of $5^{\prime}$-nucleotidase, acid phosphatase and nuclease activities.

\section{Properties of purified $L$. donovani 3 '-nucleotidase}

Stability. The partially purified enzyme fractions were stable at about $\mathrm{pH} 7$, provided that $0.1 \%$ CHAPS (or $0.1 \%$ Triton X$100)$ and $5 \%(v / v)$ glycerol were present. The DEAE-Sephacel

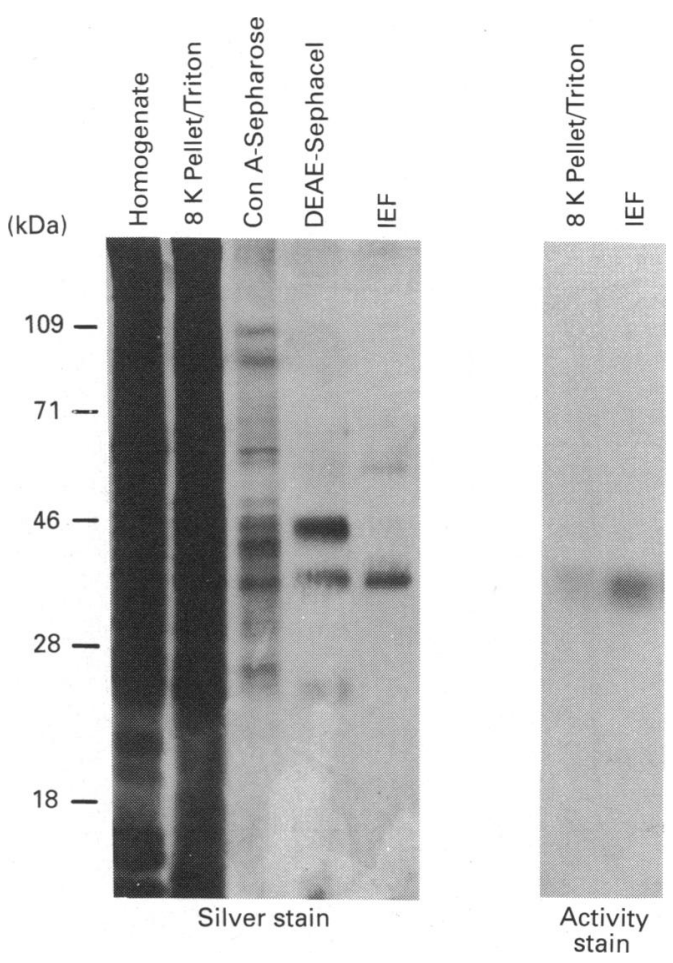

Fig. 3. SDS/PAGE of enzyme after purification steps

For details, see the Materials and methods section. Protein size markers were phosphorylase $\mathrm{b}(109 \mathrm{kDa})$, BSA $(71 \mathrm{kDa})$, ovalbumin $(46 \mathrm{kDa})$, carbonic anhydrase $(28 \mathrm{kDa})$ and $\beta$-lactoglobulin $(18 \mathrm{kDa})$.

Table 2. Substrate specificity of 3 '-nucleotidase

Reaction mixture contained purified enzyme $(0.2 \mu \mathrm{g}$ of protein $/ \mathrm{ml})$ and $2.5 \mathrm{~mm}$ of substrate or substrate analogue in $80 \mathrm{~mm}$-Hepes (pH 7.5) $/ 0.1 \%$ CHAPS.

\begin{tabular}{lc}
\hline $\begin{array}{l}\text { Substrate or } \\
\text { substrate analogue }\end{array}$ & $\begin{array}{c}\text { Relative } \\
\text { activity } \\
(\%)\end{array}$ \\
\hline 3'-IMP & 100 \\
3'-AMP & 74 \\
3'-UMP & 37 \\
3'-GMP & 21 \\
3'-CMP & 6 \\
2'd3'-AMP & $<0.1$ \\
5'-AMP & $<0.1$ \\
2'-AMP $^{\prime}$-AMP & $<0.1$ \\
3',5'-Cyclic AMP $^{\prime}$ AP & $<0.1$ \\
ADP & $<0.1$ \\
ADP & $<0.1$ \\
NAD & $<0.1$ \\
NADP & \\
Poly(A) & $<0.1$ \\
& $<0.1$
\end{tabular}

fraction was stable when stored unfrozen at $0^{\circ} \mathrm{C}$ for 6 months. The purified enzyme $(0.2 \mathrm{mg} / \mathrm{ml})$ was stable at $0^{\circ} \mathrm{C}$, but lost activity slowly when highly diluted.

pH optimum. When assayed under standard conditions and with a combination of $0.1 \mathrm{M}$-sodium acetate ( $\mathrm{pH} \mathrm{4.0-5.5),} \mathrm{-Mes}$ (pH 5.0-7.0), -Hepes (pH 6.5-8.5) and -Tris/ $\mathrm{HCl}$ (pH 7.5-9.5), a broad pH optimum of 5.5-7.5 was obtained for the purified 3'nucleotidase. The composition of the buffer had no effect on the activity. The pI of the enzyme was about 5.8 , as determined by isoelectric focusing. 


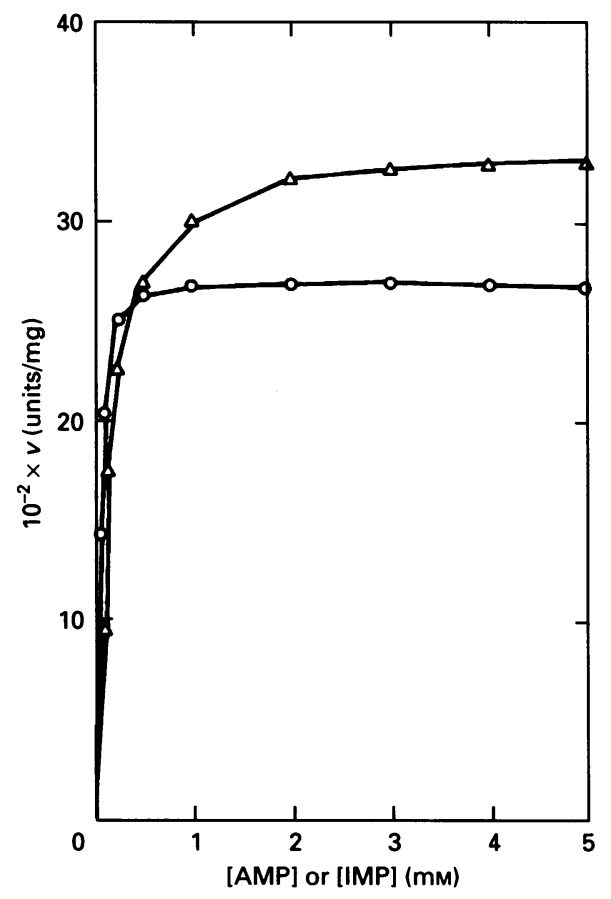

Fig. 4. L. donovani 3 '-nucleotidase activity as a function of substrate concentration

Purified enzyme was assayed for activity at different concentrations of 3'-AMP $(O)$ or $3^{\prime}$-IMP $(\triangle)$ as indicated. Data represent means of duplicate experiments (s.D. $\leqslant 5 \%$ ).

Table 3. Effect of adenine compounds on $3^{\prime}$-nucleotidase activity

Adenine compound at a concentration of $2.5 \mathrm{mM}$ (or as otherwise indicated) was added to $2.5 \mathrm{mM}-3^{\prime}$-AMP in $80 \mathrm{~mm}$-Hepes (pH 7.5) $/ 0.1 \%$ CHAPS. Reaction was started by adding purified enzyme $(0.2 \mu \mathrm{g}$ protein $/ \mathrm{ml})$.

\begin{tabular}{|c|c|}
\hline Adenine compound added & $\begin{array}{c}\text { Activity } \\
\text { remaining } \\
(\%)\end{array}$ \\
\hline None & 100 \\
\hline 5'-AMP & 31 \\
\hline 2'd3'AMP & 25 \\
\hline ADP & 18 \\
\hline ATP & 16 \\
\hline 2'-AMP & 93 \\
\hline 3',5'-Cyclic AMP & 92 \\
\hline $\operatorname{Poly}(\mathrm{A})$ & 98 \\
\hline Adenosine & 96 \\
\hline $\mathrm{NAD}^{+}$ & 97 \\
\hline NADP $^{+}$ & 98 \\
\hline$S$-Adenosylmethionine & 99 \\
\hline $\mathrm{p}\left[\mathrm{CH}_{2}\right] \mathrm{pA}(0.1 \mathrm{mM})$ & 59 \\
\hline $\mathrm{p}\left[\mathrm{CH}_{2}\right] \mathrm{pA}(0.5 \mathrm{mM})$ & 48 \\
\hline
\end{tabular}

Substrate specificity. Table 2 shows the specificity for various substrates by the purified enzyme. The enzyme hydrolysed ribonucleoside $3^{\prime}$-phosphates only. There was no activity on deoxyribonucleotides, cyclic nucleotides or $5^{\prime}$-nucleotides. The kinetics of the enzyme reaction with $3^{\prime}$-AMP or $3^{\prime}$-IMP as substrate was determined. The enzyme exhibited hyperbolic saturation behaviour with either substrate (Fig. 4). $V_{\max }$ values for $3^{\prime}$-IMP and 3'-AMP were 3420 and 2645 units/mg of protein respectively, and apparent $K_{\mathrm{m}}$ values of the enzyme for $3^{\prime}$-IMP and $3^{\prime}$-AMP were $0.28 \mathrm{~mm}$ and $0.17 \mathrm{~mm}$ respectively. Specificity

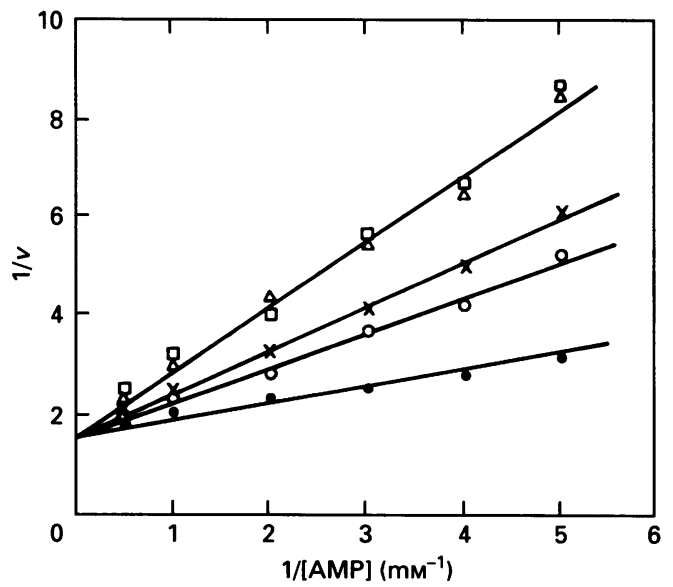

Fig. 5. Effect of $5^{\prime}$-AMP, $2^{\prime} \mathbf{d}^{\prime}$-AMP, ADP or ATP on $3^{\prime}$-nucleotidase activity

Purified enzyme was assayed for activity at different concentrations of $3^{\prime}$-AMP as indicated with $0.5 \mathrm{mM}-5^{\prime}$-AMP $(O),-2^{\prime} \mathrm{d} 3^{\prime}$-AMP $(x)$, -ADP $(\square)$ or -ATP $(\triangle)$, or without inhibitor $(\Theta)$. Data represent means of duplicate experiments (S.D. $\leqslant 5 \%$ ).

regardless of concentration is best expressed by $V_{\max } / K_{\mathrm{m}}$. The value of $\left(V_{\max } / K_{\mathrm{m}}\right.$ for $3^{\prime}$-AMP) divided by $\left(V_{\max } / K_{\mathrm{m}}\right.$ for $3^{\prime}$-IMP) is 1.28 , and by this criterion $3^{\prime}$-nucleotidase of $L$. donovani prefers $3^{\prime}$-AMP as substrate to $3^{\prime}$-IMP.

Effect of adenine compounds. The effects of various adenine compounds on $3^{\prime}$-nucleotidase activity under standard assay conditions were determined (Table 3). Poly(A), 2'-AMP, 3',5'cyclic AMP, NAD ${ }^{+}, \mathrm{NADP}^{+}$and adenosine inhibited $3^{\prime}$-AMPase activity by less than $10 \%$ at equimolar concentrations of substrate and inhibitor. 5'-AMP, ADP, ATP and 2'-deoxyadenosine $3^{\prime}$-phosphate $\left(2^{\prime} \mathrm{d} 3^{\prime}\right.$-AMP) were inhibitory $(70-80 \%$ inhibition); each was a competitive inhibitor of $3^{\prime}$-nucleotidase (Fig. 5). The $K_{\mathrm{i}}$ values of $5^{\prime}$-AMP and $2^{\prime} \mathrm{d} 3^{\prime}$-AMP for the enzyme were 0.63 and $0.5 \mathrm{~mm}$ respectively; $K_{\mathrm{f}}$ of ADP and ATP was $0.33 \mathrm{~mm}$. At concentrations of $0.1 \mathrm{~mm}$ and $0.5 \mathrm{~mm}$, adenosine $5^{\prime}$ $\left[\alpha \beta\right.$-methylene]diphosphate $\left(\mathrm{p}\left[\mathrm{CH}_{2}\right] \mathrm{pA}\right)$ (an extremely powerful inhibitor of mammalian plasma-membrane $5^{\prime}$-nucleotidase) inhibited $L$. donovani 3 -nucleotidase by only about $40 \%$ and $50 \%$ respectively. The results of the substrate- and inhibitor-sensitivities of the enzyme to adenine compounds suggest that an adenine compound must have a phosphate or polyphosphate group at the $3^{\prime}$ - or $5^{\prime}$ - position in order to bind the enzyme active site, whereas only $3^{\prime}$-AMP serves as a substrate. The following experiment demonstrated that, although $5^{\prime}$-AMP is not a substrate for $3^{\prime}$-nucleotidase, it binds to the enzyme in the presence of non-specific and specific phosphatases that could hydrolyse $5^{\prime}$ AMP in a cell homogenate: when a portion $(0.2 \mu \mathrm{g}$ of protein) of the purified enzyme was incubated with $L$. donovani homogenate ( $50 \mu \mathrm{g}$ of protein) in a standard assay mixture for $5^{\prime}$-nucleotidase (see the Materials and methods section), 5'-AMPase activity was only $10 \%$ of the activity with the homogenate alone as enzyme source in the reaction mixture (results not shown).

Other inhibition sensitivities. Inclusion of $5 \mathrm{~mm}$-EDTA in the standard reaction mixture partially inhibited (by $25 \%$ ) the enzyme activity. The activity loss caused by EDTA was completely restored by $5 \mathrm{~mm}-\mathrm{CoCl}_{2} \cdot \mathrm{Mg}^{2+}, \mathrm{Ca}^{2+}$ or $\mathrm{Mn}^{2+}$ at $5 \mathrm{mM}$ or $\mathrm{Zn}^{2+}$ ( 1 or $5 \mathrm{mM}$ ) did not reverse the enzyme inhibition caused by 5 mM-EDTA. When no EDTA was in the reaction mixture, $\mathrm{Co}^{2+}$, $\mathrm{Mg}^{2+}, \mathrm{Ca}^{2+}$ or $\mathrm{Mn}^{2+}$ at 1 or $5 \mathrm{mM}$ did not affect the enzyme activity. Commonly used phosphatase inhibitors, including molybdate, tartrate, citrate and fluoride ions, at $5 \mathrm{~mm}$ did not inhibit 3'-nucleotidase activity. $p$-Hydroxymercuribenzoate 
Table 4. Effect of $\mathrm{Zn}^{2+}$ or dithiothreitol on enzyme activity at acid and alkaline $\mathbf{p H}$

$\mathrm{ZnCl}_{2}$ or dithiothreitol at a concentration indicated was added to purified enzyme $(0.2 \mu \mathrm{g} / \mathrm{ml})$ in standard reaction buffer at $\mathrm{pH} 5.5$ or 7.5. Reaction was started by adding 3 '-AMP at a concentration of $2.5 \mathrm{~mm}$.

\begin{tabular}{ccc}
\hline & \multicolumn{2}{c}{ Activity remaining (\%) } \\
\cline { 2 - 3 } $\begin{array}{c}\text { Compound added } \\
(\mathrm{mM})\end{array}$ & $\mathrm{pH} 5.5$ & $\mathrm{pH} \mathrm{7.5}$ \\
\hline None & 98 & 100 \\
$\mathrm{ZnCl}_{2}$ & & \\
0.5 & 102 & 57 \\
1.0 & 95 & 52 \\
5.0 & 36 & 9 \\
Dithiothreitol & & \\
1.0 & 98 & 60 \\
5.0 & 40 & 11
\end{tabular}

\section{Table 5. Latency of $3^{\prime}$-nucleotidase in intact cells of $L$. donovani promastigotes}

Latency, expressed as $[(a-b) / a] \times 100$, where $a$ represents total enzyme activity in the presence and $b$ free (accessible) activity in the absence of $0.1 \%$ Triton $\mathrm{X}-100$, was measured under iso-osmotic conditions ( $0.25 \mathrm{M}$ sucrose) for $10 \mathrm{~min}$ at $37^{\circ} \mathrm{C}$.

Specific activity (units/mg of protein)

\begin{tabular}{lrrc}
\cline { 2 - 3 } Enzyme & Free & Total & Latency (\%) \\
\hline 3'-Nucleotidase & 34.3 & 50.4 & 32 \\
Alanine aminotransferase & 16.6 & 127.5 & 87 \\
& & & \\
\hline
\end{tabular}

$(0.5 \mathrm{~mm})$ inhibited the activity by $50 \%$, suggesting an involvement of thiol groups in the catalytic mechanism.

$\mathrm{Zn}^{2+}$ and dithiothreitol inhibited the 3 '-nucleotidase activity to a greater extent at alkaline $\mathrm{pH}$ than at acidic $\mathrm{pH}$. The addition of $\mathrm{ZnCl}_{2}$ or dithiothreitol at $5 \mathrm{~mm}$ to the reaction mixture at pH 7.5 resulted in approx. $90 \%$ inhibition (Table 4), whereas at pH 5.5 inhibition was about $60 \%$. Addition of $0.5 \mathrm{mM}-\mathrm{Zn}^{2+}$ or $1 \mathrm{~mm}$-dithiothreitol had no effect on the enzyme activity at the acidic $\mathrm{pH}$, whereas there was about $40 \%$ loss of activity at $\mathrm{pH}$ 7.5.

Latency of 3 -nucleotidase. The enzyme displayed low latency $(32 \%)$ as measured on intact cells, whereas the cytoplasmic alanine aminotransferase, included as an indicator of cell integrity, has high latency (Table 5). The results indicate that $3^{\prime}$ nucleotidase of $L$. donovani promastigotes is located on the outer surface of the cell membrane.

\section{DISCUSSION}

This is the first report of the purification to homogeneity of $3^{\prime}$ nucleotidase from a pathogenic parasitic protozoan. The $L$. donovani plasma-membrane-bound enzyme, which has an apparent subunit molecular mass of approx. $38 \mathrm{kDa}$, hydrolyses only ribonucleoside 3'-phosphates. Enzymes possessing 3'nucleotidase activity that have been reported purified from germinating plants [23-25], fungi [26] and recently from Crithidia [5] differ from the purified 3 -nucleotidase of $L$. donovani in their possession also of nuclease activity. The ratio of the specific activity of nuclease to that of $3^{\prime}$-nucleotidase in a typical plant nuclease $/ 3^{\prime}$-nucleotidase, also called class I nuclease, is between 20 and 50 [24], whereas the specific activity of the crithidial $3^{\prime}-$ nucleotidase is 5 times that of the nuclease [5]. This suggests that, unlike the plants which depend on their own nuclease, the parasitic Crithidia or Leishmania in particular depends to a certain extent on its host's nuclease. Besides the 3'-nucleotidase activity, the enzymes from plants and from trypanosomatid protozoa are similar in some other properties. Both types of enzymes are inhibited by EDTA, have apparent molecular masses of approx. $40 \mathrm{kDa}$ and are inhibited by $\mathrm{Zn}^{2+}$ or thiol compounds more strongly at alkaline than at acidic $\mathrm{pH}$. The properties of the purified $L$. donovani $3^{\prime}$-nucleotidase are similar to those of $3^{\prime}$ nucleotidase activity in the homogenate of L. mexicana mexicana with respect to sensitivities to EDTA and $\mathrm{Co}^{2+}$, and preference for $3^{\prime}$-AMP and 3'-IMP as substrates [2]. A higher apparent $K_{\mathrm{m}}$ $(0.58 \mathrm{mM})$ reported for the $L$. mexicana $3^{\prime}$-nucleotidase [2] than the $K_{\mathrm{m}}(0.17 \mathrm{mM})$ that we find for the purified $L$. donovani enzyme was probably an overestimation, owing to the presence of nonspecific phosphatases in the cell homogenate.

Since Leishmania parasites reside in the digestive tracts of sandfly vectors as well as the phagolysosomal system of mammalian macrophages, nucleotides resulting from degradation of nucleic acids by the host's nucleases should be available for the parasites' possible utilization. For example, 3'-nucleotides are available through nucleic acid hydrolysis in several mammalian tissues, especially the spleen [15], which is particularly easily invaded by leishmania parasites in susceptible humans. That leishmanias could utilize $3^{\prime}$-nucleotides better than the corresponding 5'-nucleotides should not be surprising, since this has been observed previously in some other micro-organisms [27]. Furthermore, since 5 -nucleotidases are abundant in mammalian cells as plasma-membrane-bound [9] as well as cytosolic enzymes [12], the parasite might be expected to compete with its host for 3 -nucleotides rather than for the corresponding 5'-nucleotides. In an attempt to assess possible competition between Leishmania and its potential mammalian host for nucleotides, we determined the reaction and inhibition kinetics of purified $L$. donovani 3 'nucleotidase with various adenine compounds. $K_{\mathrm{i}}$ values $(0.33-0.67 \mathrm{~mm})$ of the enzyme for 5'-AMP, ADP and ATP are much higher than the $K_{\mathrm{m}}$ or $K_{\mathrm{i}}$ values $(0.0001-0.1 \mathrm{~mm})$ of mammalian membrane $5^{\prime}$-nucleotidase $[28,29]$ or lysosomal soluble 5 '-nucleotidase [30] for these nucleotides, which are thus less likely to be available to inhibit the leishmanial enzyme. The following observations suggest the implication of leishmanial 3'nucleotidase in the salvage of the host's $3^{\prime}$-nucleotides: (1) location of the enzyme on the outer surface of the parasite plasma membrane; (2) a broad optimal $\mathrm{pH}$ of enzyme activity consistent with the range of environmental $\mathrm{pH}$ to which the parasite developmental stages are subjected; (3) the availability of $3^{\prime}$-nucleotides in human cells, which, however, lack $3^{\prime}$ nucleotidase, but possess $5^{\prime}$-nucleotidases with higher affinities than that of leishmanial $3^{\prime}$-nucleotidase for adenosine $5^{\prime}$ phosphates (3'-nucleotidase inhibitors); and (4) high $V_{\max }$ values of the enzyme for 3'-AMP and 3'-IMP, i.e. 2645 and $3420 \mu \mathrm{mol} / \mathrm{min}$ per $\mathrm{mg}$ respectively. The observation that $3^{\prime}$ AMP and $3^{\prime}$-IMP are the best substrates for $L$. donovani $3^{\prime}$-nucleotidase is consistent with the preference for adenine and hypoxanthine salvage in trypanosomatids [31].

L. donovani grown in medium lacking adenosine exhibited significantly greater levels of 3 '-nucleotidase activity than in nutrient-replete cells $[32,33]$, and recently it was shown that L. donovani grown in media at acid $\mathrm{pH}$ expressed approx. 5 times more 3'-nucleotidase activity than in non-acid media (D. $M$. Dwyer \& G. O. Gbenle, unpublished work). These observations suggest that the expression of leishmanial 3 -nucleotidase is regulated in certain growth conditions. Therefore the enzyme 
may be an important tool for studying regulatory signals in between the parasite's developmental stages. Purine metabolism has been recognized as an appropriate approach to controlling Leishmania species and the human diseases they cause [34], and, as shown above, $3^{\prime}$-nucleotidase may be an important purinesalvage enzyme essential for the survival of the parasite by making ribonucleosides available. However, much remains to be learnt about the regulation of leishmanial 3'-nucleotidase in vitro before differences between this enzyme and the human $5^{\prime}$ nucleotidases could be employed in a possible therapeutic strategy.

G.O.G. was the recipient of a Fogarty International Fellowship of the National Institutes of Health, U.S.A. We also thank Dr. M. Gottlieb for useful suggestions.

\section{REFERENCES}

1. Dwyer, D. M. \& Gottlieb, M. (1984) Mol. Biochem. Parasitol. 10, $139-150$

2. Hassan, H. F. \& Coombs, G. H. (1987) Mol. Biochem. Parasitol. 23, 285-296

3. Gottlieb, M., Gardiner, P. R. \& Dwyer, D. M. (1986) Comp. Biochem. Physiol. 83B, 63-69

4. Gbenle, G. O., Opperdoes, F. R. \& Van Roy, J. (1986) Acta Trop. 43, 295-305

5. Neubert, T. A. \& Gottlieb, M. (1990) J. Biol. Chem. 265, 7236-7242

6. Gottlieb, M. \& Dwyer, D. M. (1983) Mol. Biochem. Parasitol. 7, 303-317

7. Hassan, H. F. \& Coombs, G. H. (1985) Exp. Parasitol. 59, 139-150

8. McLaughlin, J. (1982) J. Immunol. 128, 2656-2663

9. DePierre, J. W. \& Karnovsky, M. L. (1974) J. Biol. Chem. 249, 7121-7129

10. Frick, G. P. \& Lowenstein, J. M. (1978) J. Biol. Chem. 253, 1240-1244

11. Itoh, R., Oka, J. \& Ozaka, H. (1986) Biochem. J. 235, 847-851

12. Meghji, P., Middleton, K. M. \& Newby, A. C. (1988) Biochem. J. 249, 695-703

Received 29 November 1991/23 January 1992; accepted 4 February 1992
13. Yamazaki, Y., Truong, V. L. \& Lowenstein, J. M. (1991) Biochemistry 30, 1503-1509

14. Drummond, G. I. \& Yamamoto, M. (1971) Enzymes 3rd Ed. 4, 337-354

15. Bushfield, M., Shoshani, I. \& Johnson, R. A. (1990) Mol. Pharmacol. 38, 848-853

16. Hammond, D. J. \& Gutteridge, W. E. (1984) Mol. Biochem. Parasitol. 13, 243-261

17. Lanzetta, P. A., Alvarez, L. J., Reinach, P. S. \& Candia, O. A. (1979) Anal. Biochem. 100, 95-97

18. Gbenle, G. O. (1985) Mol. Biochem. Parasitol. 15, 37-47

19. Reitman, S. \& Frankel, S. (1957) Am. J. Clin. Pathol. 28, 56-62

20. Smith, P. K., Krohn, R. I., Hermanson, G. T., Malim, A. K., Gartner, F. H., Provenzano, M. D., Fujimoto, E. K., Goeke, N. M., Olson, B. J. \& Klenk, D. C. (1985) Anal. Biochem. 150, 76-85

21. Laemmli, U. K. (1970) Nature (London) 227, 680-685

22. Gottlieb, M., Mackow, M. C. \& Neubert, T. A. (1988) Exp. Parasitol. 66, $108-117$

23. Kowalski, D., Kroeker, W. D. \& Laskowski, M., Sr. (1976) Biochemistry 15, 4457-4463

24. Brown, P. H. \& Ho, T. H. D. (1986) Plant Physiol. 82, 801-806

25. Olson, A. E., Janski, A. M., Fahrlander, P. D. \& Wiesner, T. A. (1982) Arch. Biochem. Biophys. 216, 223-233

26. Shishido, K. \& Ando, T. (1985) in Nucleases (Linn, S. M. \& Roberts, R. S., eds.), pp. 155-185, Cold Spring Harbor Laboratory, Cold Spring Harbor, NY

27. Balis, M. E. \& Elion, G. B. (1952) Fed. Proc. Fed. Am. Soc. Exp. Biol. 11, 183-189

28. Naito, Y. \& Lowenstein, J. M. (1981) Biochemistry 20, 5188-5194

29. Naito, Y. \& Lowenstein, J. M. (1985) Biochem. J. 226, 645-651

30. Collinson, A. R., Peuhkurinen, K. J. \& Lowenstein, J. M. (1987) in Topics and Perspectives in Adenosine Research (Gerlach, E. \& Becker, B. F., eds.), pp. 133-144, Springer-Verlag, Heidelberg

31. Marr, J. J. \& Berens, R. L. (1983) Mol. Biochem. Parasitol. 7, 339-356

32. Pastakia, K. B. \& Dwyer, D. M. (1989) Leishmaniasis, The Current Status and New Strategies for Control: NATO ASI Ser. 163, 651-658

33. Sacci, J. B., Campbell, T. A. \& Gottlieb, M. (1990) Exp. Parasitol. 71, $158-168$

34. Marr, J. J. (1983) J. Cell. Biochem. 22, 187-196 